\title{
B Acute Lymphoblastic Leukemia with t(5;14)(q31.1;q32.3); IL3-IGH
}

National Cancer Institute

\section{Source}

National Cancer Institute. B Acute Lymphoblastic Leukemia with t(5;14)(q31.1;932.3); IL3IGH. NCI Thesaurus. Code C80346.

A rare B-cell acute leukemia characterized by the presence of lymphoblasts that carry a translocation between the IL3 gene on chromosome 5 and the IGH locus on chromosome 14, (q31.1; q32.3). It results in eosinophilia. 